\title{
Non-Hodgkin's Lymphoma Presenting as Thyroid and Adrenal Gland Involvement
}

\author{
GÜrbüz ERDOĞAN, SEvim GÜLLÜ, TURAN ÇOLAK*, A. NuRI KAMEL, \\ NILGÜN BAŞKAL, AND CEMIL EKINCI** \\ Department of Endocrinology and Metabolic Disease, *Department of Internal Medicine, and \\ **Department of Pathology and Cytology, Ankara University Medical School, Ibn-i Sina Hospital, Ankara, Türkiye
}

\begin{abstract}
We report an unusual case of non-Hodgkin's lymphoma involving both the thyroid and adrenal glands. Malignant infiltration of the glands by B-cell immunoblastic type lymphoma were demonstrated by cytologic findings in needle biopsy. Staging studies showed minor nodal involvement. The patient was treated with combination chemotherapy. Simultaneous involvement of the thyroid and adrenal glands with non-Hodgkin's lymphoma is very rare. In this report, while presenting this rare coexistance, we also want to emphasize that fine-needle aspiration biopsy was useful in the diagnosis.
\end{abstract}

Key words: Lymphoma, Thyroid gland, Adrenal gland

(Endocrine Journal 44: 199-203, 1997)

LYMPHOMAS are predominantly neoplasms of lymph nodes, but involvement of other tissues can occur either at initial presentation or during relapse. Extranodal involvement by non-Hodgkin's lymphoma (NHL), especially those with diffuse architecture is common, representing from 10-48\% of cases [1,2]. The extranodal lymphomas can either be primary: localized lymphomas that appear in extranodal tissues, or secondary: occurring in the presence of node-based or disseminated disease [1]. Frequently involved sites in NHL are Waldeyer's ring, gastrointestinal tract, skin and bone [2]. By means of computed tomography (CT) and ultrasonography (US), the diagnosis for extranodal involvement improved significantly. Involvement of the thyroid or adrenal gland, either primarily or secondarily, was reported in several series [4-29]. The prevalence of thyroid involvement in lymphoma, either localized or as a

Received: May 20, 1996

Accepted: October 18, 1996

Correspondence to: Dr. Sevim Güllü, Çamkoru 88 Sitesi, Ardiç Apt. 10/4, Konutkent-Çayyolu, 06530, Ankara, Türkiye part of generalized disease, is low, accounting for $1.3-1.8 \%$ of the patients with NHL $[4,6]$. Although adrenal gland involvement was detected in 1-6\% of NHL cases by CT and US, a prevalence of 25$35 \%$ was reported in autopsy series [2, 17, 18, 24].

To our knowledge, simultaneous involvement of the thyroid and adrenal glands as a part of disseminated NHL has not been reported. Previously we reported a patient with primary thyroid and adrenal lymphoma [30].

We report here a NHL patient presenting with the involvement of two rare extranodal sitesthyroid and adrenal-simultaneously with minor nodal involvement.

\section{Case Report}

A 47 year-old woman suffering from upper abdominal pain and weight loss was referred to our department as her abdominal ultrasonographic examination demonstrated bilateral adrenal masses. On physical examination she had generalized abdominal tenderness. A hard-nodule in the right lobe of the thyroid gland and diffuse enlargement 
of the entire gland were found at palpation. Neither enlarged peripheral lymph nodes nor hepatosplenomegaly was noted.

The complete blood count was normal. The erythrocyte sedimentation rate was $80 \mathrm{~mm} / \mathrm{h}$. Serum protein electrophoresis showed no abnormality. Her serum lactic dehydrogenase level was $618 \mathrm{U} / \mathrm{L}$ (normal 101-233), alkaline phosphatase was $495 \mathrm{U} / \mathrm{L}$ (normal 98-279) and uric acid was $11.1 \mathrm{mg} / \mathrm{dL}$ (normal 3-6.5). Her urinary norepinephrine, epinephrine, vanillylmandelic acid and metanephrine levels were all within the normal ranges (32 $\mu \mathrm{g} / 24 \mathrm{~h}, 7.6 \mu \mathrm{g} / 24 \mathrm{~h}, 3.8 \mathrm{mg} /$ day, 0.21 $\mathrm{mg} /$ day, respectively). Serum free triiodothyronine was $6.6 \mathrm{pmol} / \mathrm{L}$, free thyroxine was $19.1 \mathrm{pmol} / \mathrm{L}$, and TSH was $1.1 \mu \mathrm{Iu} / \mathrm{mL}$ and were also within the normal ranges. She was negative for thyroid autoantibodies. Plasma ACTH was $34.9 \mathrm{pg} / \mathrm{ml}$ (normal 10-50), cortisol was $14.1 \mu \mathrm{g} / \mathrm{dL}$ (normal 7-25) and urine free cortisol was $47.1 \mu \mathrm{g} / 24 \mathrm{~h}$ (normal 35-120). The serum cortisol concentration increased from $14.1 \mu \mathrm{g} / \mathrm{dL}$ to $51 \mu \mathrm{g} / \mathrm{dL}$ at $60 \mathrm{~min}$ with short ACTH (Synacthen) stimulation test.

Thyroid ultrasonography demonstrated a $34 \times$ $20 \times 25 \mathrm{~mm}$ hypoechoic nodule (Fig. 1a) which was found to be hypoactive, on Tc- $99 \mathrm{~m}$ scan, at the right lobe of the gland.

Re-performed abdominal US showed echolucent adrenal masses (right $151 \times 103 \times 80 \mathrm{~mm}$, left $139 \times$ $108 \times 99 \mathrm{~mm}$ ).

CT confirmed adrenal masses as well as enlarged lymph nodes in the pelvis (Fig. 2a).

Fine needle aspiration biopsies of both adrenal (US-guided) and thyroid glands were done. The cytologic specimens were stained by the MayGrünwald-Giemsa method as air dried smears. Lymphoid cells showing blastic characteristics: large hyperchromatic nuclei, homogeneous basophilic or violet basophilic cytoplasms, large centrally localized single nucleoli and cytoplasmic microvacuolization were observed in all specimens (Fig. $3 \mathrm{a}, \mathrm{b}$ ). In immunohistochemical studies, $\mathrm{B}$ cell type was considered to be positive for CD 45 (pan-lymphocyte marker) and CD 20 (B-cell marker) antigens. The specimens were negative for CD 3 (T-cell marker) antigen. On the basis of these findings a diagnosis of high-grade immunoblastic type lymphoma was made.

The chest $x$-ray was normal. For staging Waldeyer's ring examination, gastrointestinal
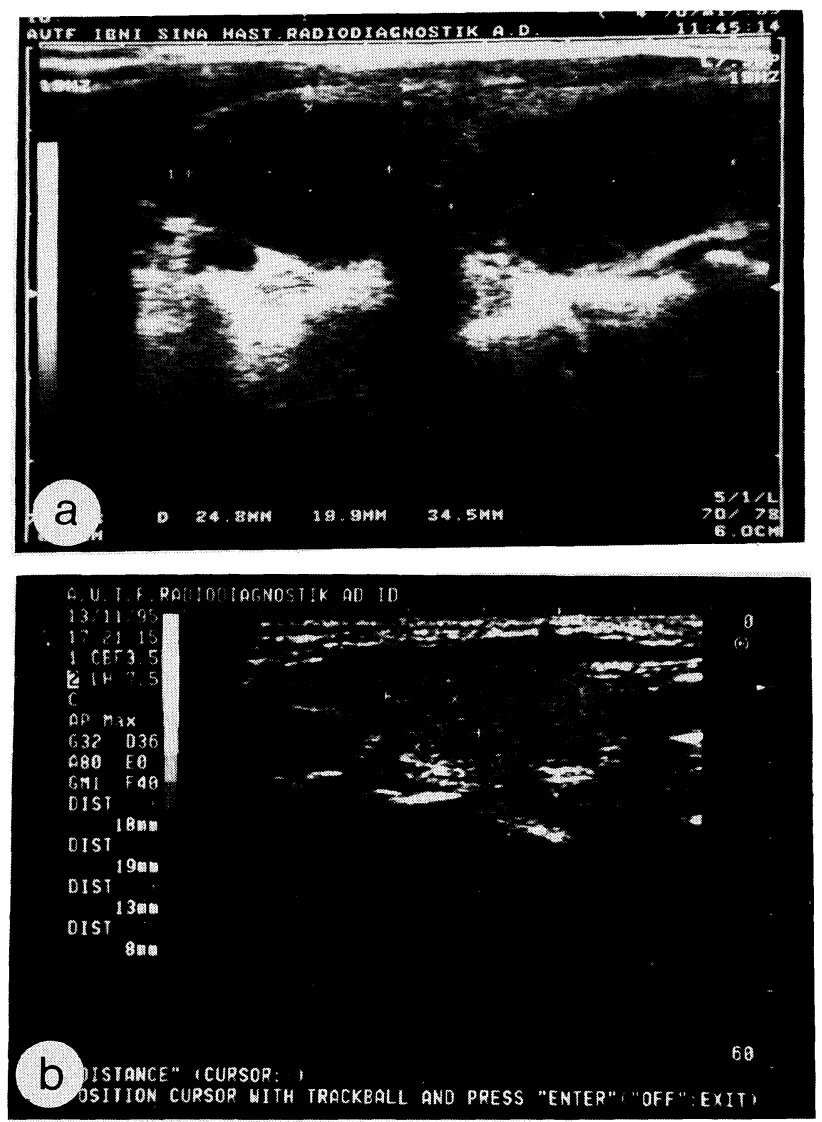

Fig. 1. Thyroid nodule of the patient a: before, b: after chemotherapy.

series, whole body bone scintigraphy, head and thorax CT, biopsies of the small intestine, liver and bone-marrow, and cerebrospinal fluid cytologic examination were performed and revealed no abnormal findings.

The patient developed a fever and night sweats during the follow-up in our clinic and in view of the above mentioned findings she was regarded as having stage IV B NHL.

She received $\mathrm{CHOP}$ regimen (cyclophosphamide $750 \mathrm{mg} / \mathrm{m}^{2}$ doxorubicine $50 \mathrm{mg} / \mathrm{m}^{2}$ and vincristine $1.4 \mathrm{mg} / \mathrm{m}^{2}$ i.v. on the first day and prednisolone $100 \mathrm{mg} /$ day po for five days). The thyroid nodule and adrenal masses both regressed after the third course of the chemotherapy (Figs. $1 b$ and $2 b$ ). Apart from leucopenia, no complication was observed with this regimen. 

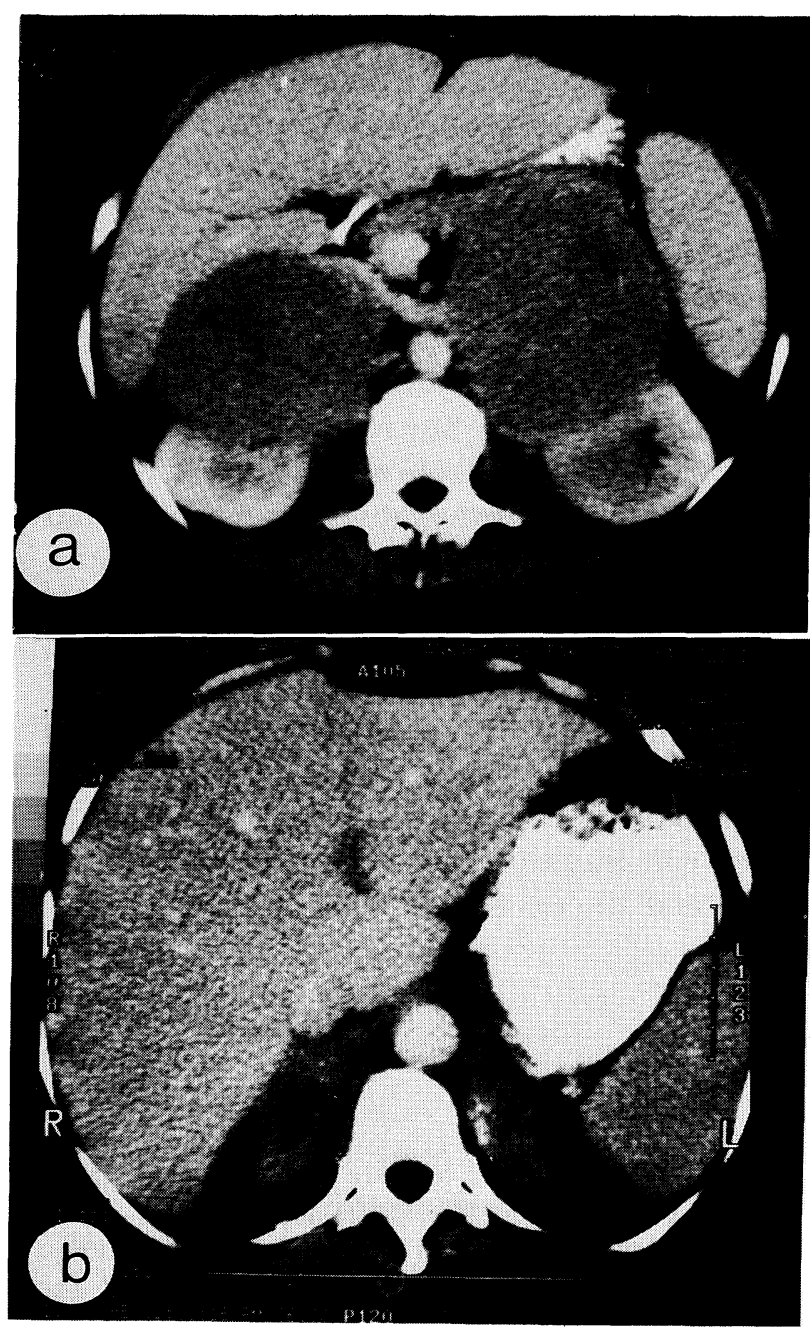

Fig. 2. Surrenal masses of the patient a: before, b: after third course of treatment.

\section{Discussion}

A case with high-grade immunoblastic NHL showing the involvement of both the thyroid and adrenal glands and pelvic lymph nodes is presented.

About one-third of patients with NHL have extranodal involvement at presentation [1, 2]. Although the gastrointestinal tract is the most common site of extranodal lymphomas (ENL), the involvement of almost all tissues has been reported [1]. The majority of ENL are of B-cell origin and usually of the diffuse large cell type, as in our case $[1,13]$.

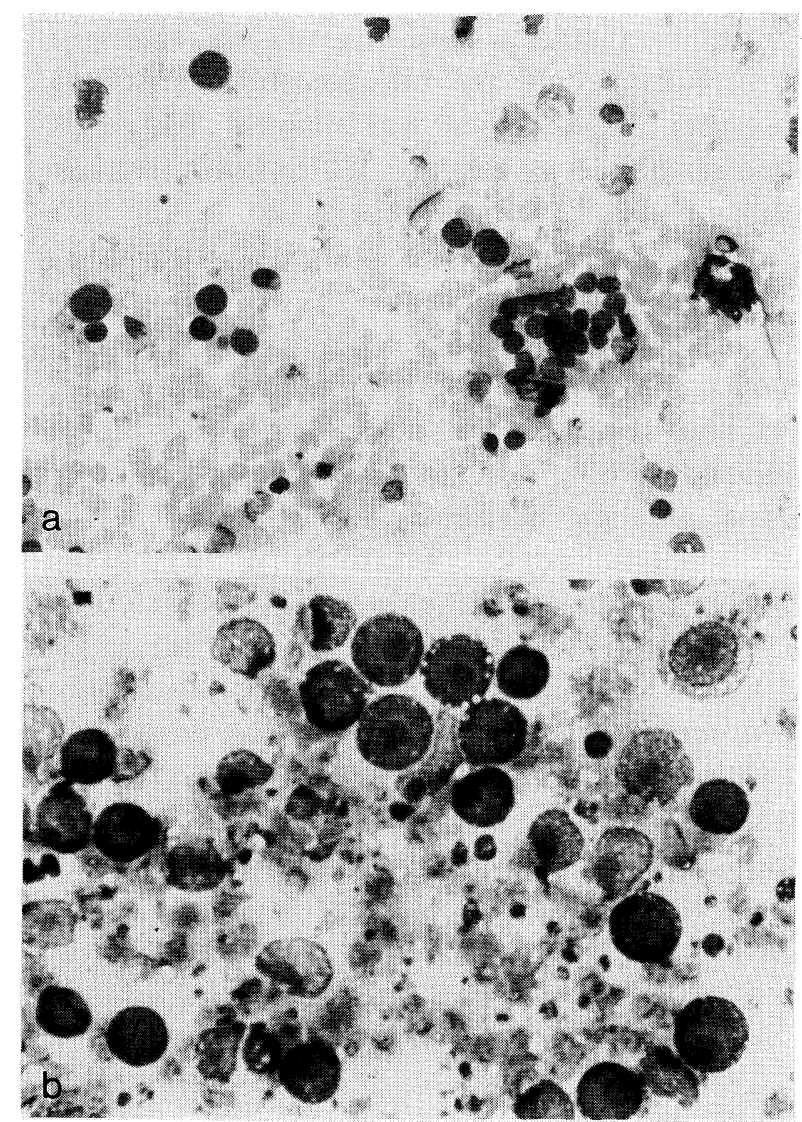

Fig. 3. Cytologic specimens of a, thyroid gland; atypical lymphoid cells and follicular epithelial cell groups (200 × , May-Grünwald-Giemsa), b, adrenal gland; blastic lymphoid cells with apparent nucleoli $(400 \times$, May-Grünwald-Giemsa), both demonstrating highgrade immunoblastic type lymphoma.

Involvement of the thyroid gland is a rare manifestation of NHL. Primary NHL of the thyroid accounts for less than $3 \%$ of ENL with most of the cases occurring in the gland of Hashimoto's thyroiditis $[12,13,15]$. Secondary involvement of the gland as a part of disseminated disease was reported in $0.29-0.7 \%$ of NHL cases.

The ultrasonographic appearence of thyroid lymphoma was defined as hypoechoic patterns [15, 16]. Nodular enlargement is the most frequent pattern but diffuse goiter can also be seen [16].

Adrenal involvement in NHL can either be unilateral or bilateral [17-30]. The frequency of bilateral and unilateral presentations are similar in secondary lymphomatous adrenal involvement. NHL of the adrenal glands should be considered in the differential diagnosis of adrenal masses. The 
CT and US appearances of adrenal enlargement due to lymphoma are nonspecific. Adrenal involvement in our patient was bilateral. Although adrenal insufficiency due to NHL involvement has been reported by some authors [20, 22-27], no clinical or laboratory evidence of such process was present in our patient.

Fine-needle aspiration biopsy (FNAB) has become a well established, cheap and well tolerated diagnostic tool with low morbidity for many diseases. Cytologic diagnosis of malignant lymphoma can be made by means of FNAB. Immunohistochemical staining of aspirates increases the diagnostic value of FNAB $[15,31]$. We performed FNAB on both adrenal-US-guidedand thyroid glands. The cytology showed large cell immunoblastic type lymphoma on both sites. CD 45 (pan-lymhocyte marker) and CD 20 (B-cell marker) positivity and CD3 (T-cell marker) negativity in an immunocytochemical study showed the B-cell origin of the lymphoma.

To our knowledge no such case with simul- taneous involvement of these two endocrine glands - the thyroid and adrenal—in NHL has been reported. Previously we reported a case of primary NHL of the adrenal and thyroid glands with no nodal involvement [30], but the patient presented in this paper had both nodal and extranodal involvement.

$\mathrm{CHOP}$ is suggested as the standard regimen for diffuse aggressive lymphomas. Our patient did well with this therapy. She showed partial remission with no important side effects.

In conclusion, careful evaluation of the thyroid gland by palpation for nodular enlargement and ultrasonography for hypoechoic lesions, and the adrenal glands by computed tomography in addition to lymph-node areas, should be done in patients with NHL. Fine needle aspiration biopsy should also be carried out in the discovered masses since an accurate evaluation of the extend of the disease can increase the stage and change the method and success rate of the treatment.

\section{References}

1. Salhany KE, Pietra GG (1993) Extranodal lymphoid disorders. Am J Clin Pathol 99 (4): 472-485.

2. Straus DJ, Filippa DA, Lieberman PH, Koziner B, Thaler HT, Clarkson BD (1981) The non-Hodgkin's lymphomas: 1. A retrospective clinical and pathologic analysis of 499 cases diagnosed between 1958 and 1969. Cancer 51: 101-109.

3. d'Amore F, Christensen BE, Brincker H, Pedersen NT, Thorling K, Hastrup J, Pedersen M, Jensen MK, Johansen P, Andersen E, Bach B, Sorensen E (1991) Clinicopathological features and prognostic factors in extranodal non-Hodgkin's lymphomas. Eur J Cancer 27: 1201-1208.

4. Chak LY, Hoppe RT, Burke JS, Kaplan HS (1981) Non-Hodgkin's lymphoma presenting as thyroid enlargement. Cancer 48: 2712-2716.

5. Rasbach DA, Mondschein MS, Harris NL, Kaufman DS, Wang C (1985) Malignant lymphoma of the thyroid gland: A clinical and pathologic study of twenty cases. Surgery 98: 1166-1170.

6. Tennvall J, Sthal EC, Akerman M (1987) Primary localized non-Hodgkin's lymphoma of the thyroid: A retrospective clinicopathological review. Eur $J$ Surg Oncol 13: 297-302.

7. Grimley RP, Oates GD (1980) The natural history of malignant thyroid lymphomas. Br J Surg 67: 475477.
8. Hamburger JI, Miller M, Kini (1983) Lymphoma of the thyroid. Ann Intern Med 99: 685-693.

9. Compagno J, Oertel JE (1980) Malignant lymphoma and other lymphoproliferative disorders of the thyroid gland: A clinicopathologic study of 245 cases. Am J Clin Pathol 74: 1-11.

10. Lindsay S, Dailey M (1955) Malignant lymphoma of the thyroid gland and its relation to Hashimoto disease: A clinical and pathologic study of 8 patients. J Clin Endocrinol Metab 15: 1332-1353.

11. Mizukami $Y$, Michigishi $T$, Nonomura A, Nakamura S, Hashimoto T, Katsuda S, Otake S, Matsubara F (1990) Primary lymphoma of the thyroid: A clinical, histological and immunochemical study of 20 cases. Histopathology 17: 201-209.

12. Aozasa K, Inoue A, Tajima K, Miyouchi A, Matsuzuka F, Kuma K (1986) Malignant lymphomas of the thyroid gland: Analysis of 79 patients with emphasis on histologic prognostic factors. Cancer 58: 100-104.

13. Aozasa K, Ueda T, Katagiri S, Matsuzuka F, Kuma K, Yonezawa T (1987) Immunologic and immunohistologic analysis of 27 cases with thyroid lymphomas. Cancer 60: 969-973.

14. Tsang RW, Gospodarowicz MK, Sutcliffe SB, Sturgeon JFG, Panzarella T, Patterson BJ (1993) NonHodgkin's lymphoma of the thyroid gland: 
Prognostic factors and treatment outcome. Int J Radiation Oncology Biol Phys 27: 599-604.

15. Matsuzuka F, Miyauchi A, Katayama S, Narabayashi I, Ikeda H, Kuma K, Masahiro S (1993) Clinical aspects of primary thyroid lymphoma: Diagnosis and treatent based on our experience of 119 cases. Thyroid 3: 93-99.

16. Kasagi $K$, Hatabu $H$, Tokuda $Y$, Yamabe $H$, Hidaka A, Yamamoto K, Lida Y, Misaki T, Mori T, Endo K, Konishi J (1991) Lymphoproliferative disorders of the thyroid gland: Radiological appearances. $\mathrm{Br} J$ Radiology 64: 569-575.

17. Glazer HS, Lee JKT, Balfe DM, Mauro MA, Griffith R, Sagel SS (1983) Non-Hodgkin's lymphoma: Computed tomographic demonstration of unusual extranodal involvement. Radiology 149: 211-217.

18. Paling MR, Williamson BRJ (1983) Adrenal involvement in non-Hodgkin lymphoma. $A m J$ Radiology 141: 303-305.

19. Feldberg MAM, Hendriks MJ, Klinkhamer AC (1986) Massive bilateral non-Hodgkin's lymphomas of the adrenals. Urol Radiol 8: 85-88.

20. Pool MO, Janssen MJ, Van der Valk P, Groeneveld ABJ (1991) Adrenocortical insufficiency: A rare presentation of non-Hodgkin's lymphoma. J Intern Med 229: 377-380.

21. Curry NS, Chung CJ, Potts W, Bissada N (1993) Isolated lymphoma of genitourinary tract and adrenals. Urology 41: 494-498.

22. Khan S, Raby N, Michell M (1990) Case report: NonHodgkin's lymphoma confined to the adrenal glands presenting with Addison's disease. Clin
Radiol 42: 63-64.

23. Dobnig H, Silly H, Öblinger W, Neuauer M, Leb G, Krejs GJ (1992) Successful treatment of primary adrenal insufficiency due to malignant nonHodgkin's lymphoma. Clin Investig 70: 938-941.

24. Gamelin E, Beldent V, Rousselet MC, Rieux D, Rohmer V, Ifrah N, Boasson M, Bigorgne JC (1992) Non-Hodgkin's lymphoma presenting with primary adrenal insufficiency. Cancer 69: 2333-2336.

25. Carey RW, Harris N, Klilman B (1987) Addison's disease secondary to lymphomatous infiltration of the adrenal glands. Cancer 59: 1087-1090.

26. Huminer D, Garty M, Lapidot M, Leiba S, Borohov H, Rosenfeld JB (1988) Lymphoma presenting with adrenal insufficiency. Am J Med 84: 169-172.

27. Serrano S, Tejedor L, Garcia B, Hallal H, Polo JA, Alguacil G (1993) Addisonian crisis as the presenting feature of bilateral primary adrenal lymphoma. Cancer 71: 4030-4033.

28. Falchook FS, Allard JC (1991) CT of primary adrenal lymphoma. J Comp Assist Tomography 15: 1048-1050.

29. Alvarez-Castells A, Pedraza S, Tallada N, Castella E, Gifre L, Torrents C (1993) CT of primary bilateral adrenal lymphoma. J Comp Assist Tomography 17: 408-409.

30. Başkal N, Erdoğan G, Kamel AN, Dagci ŞŞ, Akyar S, Ekinci C (1992) Localized non-Hodgkin's lymphoma of the thyroid and adrenal glands. Endocrinol Japon 39: 269-276.

31. Sandrasegaran K, Robinson PJ, Selby P (1994) Staging of lymphoma in adults. Clin Radiol 49: 149161. 